\title{
SUSTAINABLE FARMING PRODUCTION AND ITS IMPACT ON THE NATURAL ENVIRONMENT - CASE STUDY BASED ON A SELECTED GROUP OF FARMERS
}

Piotr PRUS, UTP University of Science and Technology in Bydgoszcz, Faculty of Agriculture and Biotechnology, Department of Economics and Advising in Agribusiness, ul. Fordońska 430, 85-790 Bydgoszcz, Polandpiotr.prus@utp.edu.pl

\begin{abstract}
The idea of sustainable farming entails farming production management which allows for the efficient use of natural resources in order to achieve financial profit, while respecting the laws of nature and meeting expectations of society at the same time. The idea is interdisciplinary and incorporates many facets. The author analysed numerous methods of production technology which exert influence on the natural environment. The aim of the research was to evaluate if - and to what extent - agricultural production of the examined farms was sustainable. The empirical data was collected by means of the diagnostic interview technique. The poll was carried out between 2014 and 2017 among 155 respondents. The research showed that the majority of the polled farmers adhered to the sustainable farming production guidelines and tried to extend their knowledge of the subject matter.
\end{abstract}

Keywords: sustainable development, farming, farming production

JEL classification: Q01, Q10

\section{INTRODUCTION}

Sustainable development is one of the main objectives of the European Union (Roman, 2016). According to its principles, the economic aspect of the development should perceive society and the natural environment not as its inhibitors but rather as stimulants. Sustainable development can be stimulated by numerous factors such as technological advances, raising awareness among country dwellers, involving them in decision-making processes and sharing the responsibility, creating new jobs, promoting activity and entrepreneurship, and more effective use of natural resources and labour (Paluch and Plonka, 2011). This idea is reflected in the government's financial policy realized within the EU's Common Agricultural Policy (Desjeux et al., 2015; Koloszko-Chomentowska et al., 2015; Kowalska et al., 2016; Marcysiak and Prus, 2009). Sustainable development in agriculture means such programming of farming production so that it makes reasonable use of natural resources and the environment. It provides sufficient amounts of food while maintaining its high quality (Bojar et al., 2014). Typical features of sustainable farming are (Krasowicz, 2012): maintaining high fertility of the soil, adjusting the type of production, the selection of crops and animal breeds to the natural, economical and organizational conditions, balanced distribution of organic matter in the soil, balanced distribution of fertilizers (organic and mineral), high crop coverage index, integrated crop protection schemes, observing the fundamentals of agricultural techniques and animal husbandry, farmers having access to suitable machines and equipment, observing Good Agricultural Practice guidelines, effective organization of labour and competent running of farms, respecting existing bonds between farms and surrounding rural areas, equalling farmers' income with non-farming jobs. This type of management allows farmers to make reasonable profit, maintain biodiversity while exerting little pressure on the environment, which typically occurs in so-called conventional/industrial (non-sustainable) farming. Only by using appropriate production techniques and methods can farmers achieve the aforementioned advantages, while maintaining fertility of the soil at the same time. In sustainable farming the emphasis is placed on farm management know-how, instead of material input. In this model farmers' qualifications and competence are preconditions of successful and effective agricultural planning, which combines economic goals, conservation of the natural environment and people's expectations (Kalinowski, 2010; Koreleska, 2016; Paluch and Plonka, 2016). The aim of the study was to evaluate whether - and to what extent - farmers follow sustainable farming guidelines, taking into account individual conditions of a farm. 


\section{MATERIAL AND THE RESEARCH METHOD}

Sustainable farming is a complex and interdisciplinary notion which has many facets. It looks at numerous aspects of agricultural production. This study focuses on several key features of sustainable farming. They determine technology of agricultural production and its pressure on the natural environment. They include production type, the manner in which crops obtain vital nutrients, different ways of maintaining and boosting soil fertility, and different methods of pest control. What is more, the author examined sources of information about sustainable farming available to respondents.

There was chosen the diagnostic poll method to collect empirical data. The survey was conducted between $2014-$ 2017 among a group of 155 students of Agriculture. They either had been farm owners or worked on farms managed by their parents whom they would eventually succeed. Thus, the group was pre-selected instead of being randomly chosen. The respondents' exhibited above average interest in the subject when compared to other farmers. They pursued the subject of sustainability in farming and strove to continually increase their competence in this matter. Rather than finish their education after graduating from vocational school or agricultural college, they enrolled on agricultural university to pursue or extend a career in their current or future job in agriculture. It can be assumed that soon they will shape the image of agriculture in Kujawko-pomorskie or other neighbouring provinces. So, according to the diffusion of innovation theory (Rogers, 1995; van den Ban and Hawkins, 1996; Zawisza and Pilarska, 2005), the studied group of students can be considered as innovators, which will be followed by others (early adopters, then the early and late majority of followers).

The obtained empirical data was analysed using the statistical hypothesis test. The analysis was to reveal relationships between the respondents' answers and the selected variable - a farm's arable land, which is a key factor that determines its production potential (Poczta et al., 2009; Rys-Jurek 2008; Rys-Jurek 2009). The respondents were divided into two groups depending on their farm size. There was chosen 15 ha as the boundary value, based on farm average size data in the Kujawsko-pomorskie province in the previous years (Ogloszenie..., 2014; Ogloszenie..., 2015; Ogloszenie..., 2016; Ogloszenie..., 2017): 15.30 ha (2014), 15.40 ha (2015), 15.51 ha (2016) and 15.77 ha (2017). The figures for the whole country were: 10.48 ha (2014), 10.49 ha (2015), 10.56 ha (2016) and 10.65 ha (2017) respectively. The data gathered in the course of the study were analysed in two stages. First, there was verified the occurrence of the relationship by using the $\chi^{2}$ (chi-squared) test. Then the author measured its direction and force. The analysis was performed for materiality level $\alpha=0.01$, for $\mathrm{H}_{0}$ and $\mathrm{H}_{1}$ hypotheses, where $\mathrm{H}_{0}$ indicates the lack of the relationship, and $\mathrm{H}_{1}$ indicates its occurrence. Having confirmed the relationship between the variables exists, the author proceeded to evaluate its character (direction) and force, using the Pearson's contingency coefficient [C] and the convergence coefficient [g]. Since the convergence coefficient $[\mathrm{g}]$ may assume different values depending on whether variables are treated as dependent or independent, it has been calculated twice for both cases: $\mathrm{g}_{\mathrm{rc}}$ (row to column convergence coefficient) and $\mathrm{g}_{\mathrm{cr}}$ (column to row coefficient) (Babbie, 2003; Dziekanski, 2016; Dziekanski, 2017; Gruszczynski, 1986; Sobczyk 2004). The statistical calculation proved that differences among the respondents' opinions from both groups were statistically significant only in the case of the declared main production type (Table 1).

Table 1. Significant differences in respondents' declarations in comparison with their farm size - the $\chi 2$ test results, Pearson's contingency coefficient $[\mathrm{C}]$ and the convergence coefficient $[\mathrm{g}]$

\begin{tabular}{|l|r|r|r|c|c|}
\hline \multicolumn{1}{|c|}{ Specification } & \multicolumn{5}{c|}{ Farm size } \\
\cline { 2 - 6 } & $\chi^{2} \alpha=0,01$ & \multicolumn{1}{c|}{$\chi^{2}$} & \multicolumn{1}{c|}{$\mathrm{C}$} & \multicolumn{1}{c|}{$\mathrm{g}_{\mathrm{rc}}$} & \multicolumn{1}{c|}{$\mathrm{g}_{\mathrm{cr}}$} \\
\hline Main production type & 9.210 & $16.015^{*}$ & 0.306 & 0.000 & 0.105 \\
\hline Providing crops with nutrients & 9.210 & 2.003 & - & - & - \\
\hline Procedures for improving and maintaining high fertility of soil & 9.210 & 0.757 & - & - & - \\
\hline Crop protection methods & 13.277 & 1.807 & - & - & - \\
\hline Sustainable farming information sources & 18.475 & 2.104 & - & - & - \\
\hline
\end{tabular}

*figure significance for $\alpha=0.01$

\section{RESEARCH RESULTS AND DISCUSSION}

Sustainable farming recommends farmers to grow crops and keep livestock (Duer et al., 2004; Lantinga et al., 2000), and such type of mixed production was declared by most of the respondents (Table 2). It can be noted that students living on smaller farms either more frequently declared the mixed production or they favoured livestock production over growing crops. This can be explained by the small size of their farms, where the lack of arable land rendered growing crops economically not viable.

Table 2. Main type of production on the studied farms

\begin{tabular}{|l|r|r|r|r|r|r|}
\hline \multirow{2}{*}{$\begin{array}{c}\text { Production } \\
\text { type }\end{array}$} & \multicolumn{2}{c|}{ Up to 15 ha } & \multicolumn{2}{c|}{ Over 15 ha } & \multicolumn{2}{c|}{ Total } \\
\cline { 2 - 7 } & No. & \multicolumn{2}{c|}{$\%$} & \multicolumn{1}{c|}{ No. } & \\
\hline Crops & 5 & 8.8 & 32 & 32.7 & 37 & 23.9 \\
\hline Livestock & 12 & 21.1 & 6 & 6.1 & 18 & 11.6 \\
\hline Mixed & 40 & 70.1 & 60 & 61,2 & 100 & 64.5 \\
\hline Total & 57 & 100.0 & 98 & 100.0 & 155 & 100.0 \\
\hline
\end{tabular}

The total elimination of animal production may result in disagrarisation, especially in the case of smaller farms. This in turn creates a potential risk of abandoning agricultural production altogether (Wojewodzic et al., 2015). Not surprisingly, it is 
the combination of both types of production which is the most beneficial. Combining crop production and livestock raising allows for using certain amount of crops as animal feed. On the other hand, animals can provide organic fertilizers (solid and liquid manure), which is an ideal supplement of the mineral fertilizers. In certain cases it can be the sole source of nitrogen, phosphorus and potassium - the necessary nutrients which boost crop growth. Using different forms of fertilizing techniques can be beneficial both for farmers and the environment. By relying more on animal and green manure (crops grown for the purpose of being used as fertilizer) farmers can become more independent from fluctuations in prices of mineral fertilizers. This, however, requires farmers to have the necessary know-how and expertise in combining and applying different types of mineral and natural fertilizing techniques. For example, farmers must accurately calculate the appropriate amounts of nitrogen, phosphorus and potassium in all types of fertilizer (Krasowicz, 2012; Stefanova and Salek, 2013). Fertilizers (including natural ones) - if used excessively - cause eutrophication, and lead to soil and water contamination. The correct amount of fertilizers depends on individual nutrient requirements of different plants as well as the type of soil in which they grow. Farmers must also adhere to fertilizing times. By observing them, they can make a full use of nutrients contained in mineral and natural fertilizers (Duer et al., 2004; Krasowicz, 2012). The vast majority of respondents declared using mineral and organic fertilizers as the main source of nutrients (Figure 1). Much less frequently they used for this purpose cultivation of legumes, which are a valuable source of nitrogen compounds.

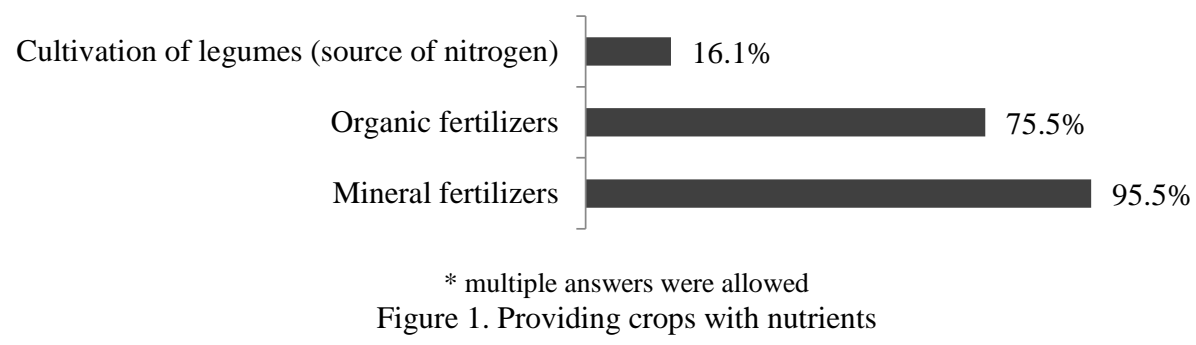

When considering a single farm, one of the major goals of sustainable agriculture is maintaining soil fertility. There are several techniques, which can be employed to achieve this goal (Krasowicz, 2012), namely: a proper crop rotation using Legume plants as green fertilizer, and - as mentioned above - combining natural and mineral fertilizers. Making use of harvest remains and ploughing straw also have beneficial effect, boosting fertility of the soil by building up humus and increasing biodiversity (Duer et al., 2004; Krasowicz, 2012). More than a half of the respondents knew and applied these techniques (Figure 2). About half of the respondents composted organic fertilizers, which contributed to the optimum utilization of the contained nutrients. When moved onto a field, fertilizer should be immediately ploughed in order to mix with the soil - an operation performed by the majority of the polled farmers. It may be impeded, however, by unfavourable weather conditions, machine failure or a farmer's sickness.

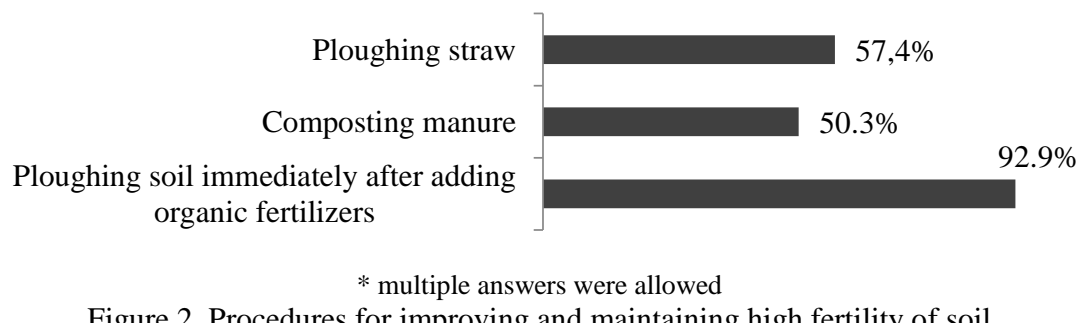

Figure 2. Procedures for improving and maintaining high fertility of soil

The most popular method of fighting weed, disease and pest in crops was using chemicals (Figure 3). Most of the farmers were aware of and observed the fact that it is possible to limit the amount of chemicals by adhering to optimum dates of application. Crop protection is an operation, which should be performed reasonably and in accordance with sustainable farming guidelines. It involves the correct sequence of crop rotation, using mechanical and biological protection, and choosing crops resilient to pest and disease (Duer et al., 2004; Kapitsa 2012; Krasowicz, 2012; Sigvald 2012; Torstensson 2012). Unfortunately, less than a half of the respondents admitted following these guidelines.

Knowledge base is the key factor when making optimal and informed decisions in farming (Prus and Drzazdzynska, 2017). The term "knowledge" should not be understood just as "an idea". On the contrary, it encompasses the whole system (Dacko and Dacko, 2009) and its application, including methods and tools necessary to manage a farm (Drangert et al., 2017). The polled farmers pointed at knowledge obtained in the course of study, as well as the internet as the main sources of information about sustainable farming (Figure 4). Among other, less important sources of information they mentioned: agricultural periodicals, various types of courses and training, television and radio programmes and professional textbooks. Among other sources of information there were mentioned: the nearest family and other farmers (including neighbours), as well as participation in organized contests related to this subject. 


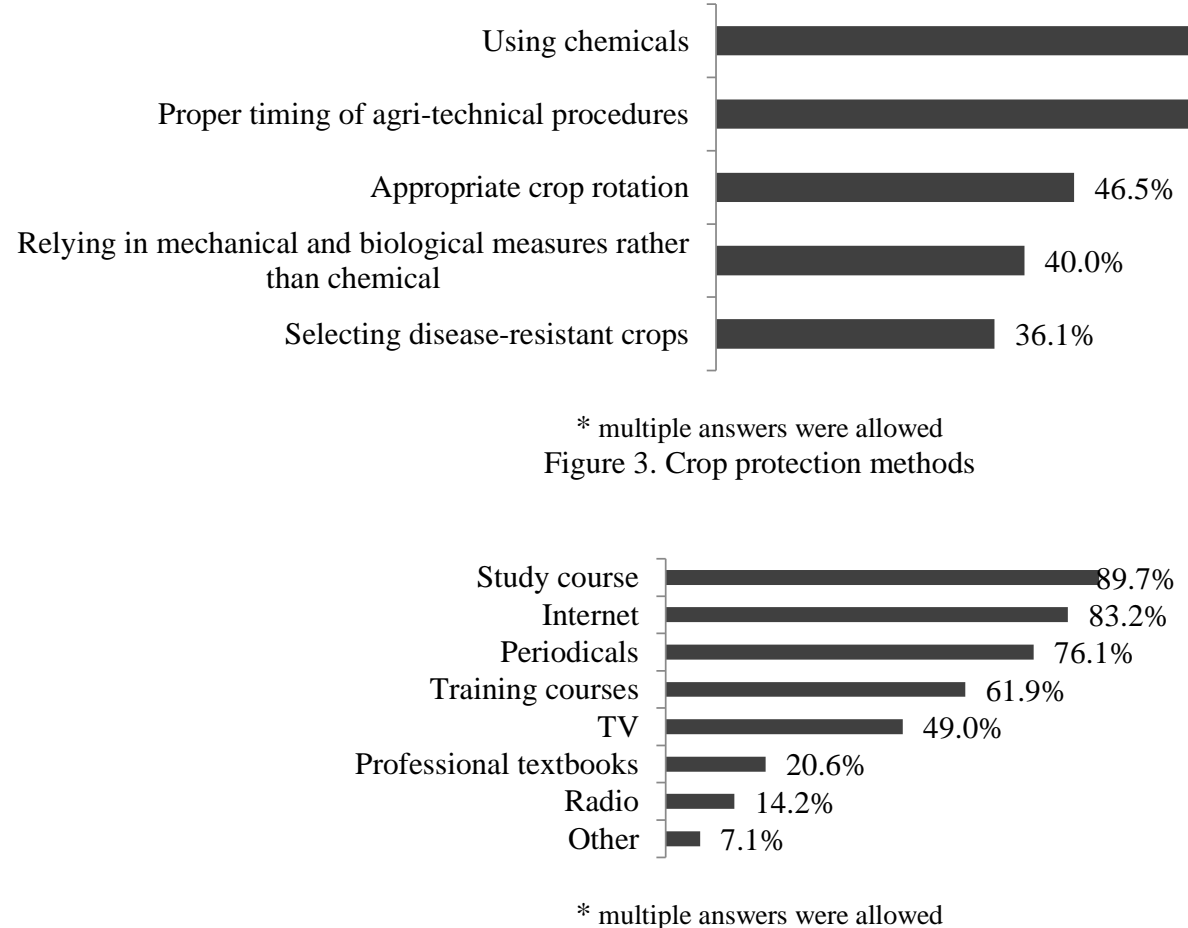

Figure 4. Sustainable farming information sources

\section{CONCLUSIONS}

The results of the research showed that the majority of the respondents were using basic technics and methods consistent with the principles of sustainable agricultural production. The polled farmers maintained mixed production (crops and livestock). It must be stressed that this type of production was particularly popular with students coming from smaller farms. The majority of the respondents (irrespectively of their farm size) declared using both mineral and organic fertilizers, as well as strived to maintain fertility of the soil. Unfortunately, not all of these procedures were flawless. As far as crop protection was concerned, many farmers relied heavily on using the chemical methods. However, due to the complexity of the notion of sustainable farming, it is hard to find a farmer who follows all these rules to the letter. On the positive side, most of the respondents were interested in developing their knowledge of sustainable farming. Hopefully, they will become leaders who, by setting good examples, will be observed and followed by local farmers. The key to the sustainable development of rural areas and individual farms in Poland seems to be in raising the ecological awareness among farmers, particularly those who are starting their careers. Therefore it is very important that during the course of their study they have an opportunity to expand their competence and rely on up-to-date information. In this way, they can better understand that sustainable farming is a complex type of agricultural activity, which combines economic and social goals with the requirements of the natural environment (Stareike, 2015). Undoubtedly, further subsidies and schemes offering financial assistance, either from own resources of the government or the EU support programmes, are necessary for such type of farming, which will combine consumers' qualitative and quantitative expectations, alleviate farming impact on the natural environment, and secure income for the producers.

\section{REFERENCES}

1. Babbie, E. 2003. Badania spoleczne w praktyce (Social studies in practice), PWN, Warszawa. [In Polish]

2. Bojar, W., Dzieza, G., Sikora, M., Spiewak, J., Wyszkowska, Z., Januszewski, A., Zoltowski, M. 2014. Wybrane metody ograniczania dzialania czynnikow ryzyka w rolnictwie w swietle wspolczesnych wyzwan (Selected methods of reducing risk factors in agriculture in the light of contemporary challenges). Roczniki Naukowe Ekonomii Rolnictwa i Rozwoju Obszarow Wiejskich, Vol. 101, Iss. 4, pp. 7-18. [In Polish]

3. Dacko, M., Dacko, A. 2009. Management of the Natural Environment. A Systemic Approach. Polish Journal of Environmental Studies, Vol. 18, No. 2, pp. 145-150.

4. Drangert, J.O., Kielbasa, B., Ulen, B., Tonderski, K., Konderski, A. 2017. Generating applicable environmental knowledge among farmers. Experiences from Poland. Agroecology and Sustainable Food Systems, Vol. 41, 6, pp. 671-690. https://doi.org/10.1080/21683565.2017.1310786

5. Desjeux, Y., Dupraz, P., Kulhman, T., Paracchini, M.L., Michels, R., Maigne, E., Reinhard, S. 2015. Evaluating the impact of rural development measures on nature value indicators at different spatial levels: applications to France and The Netherlands. Ecological Indicators, Vol. 59, pp. 41-61. https://doi.org/10.1016/j.ecolind.2014.12.014

6. Duer, I., Fotyma, M., Madej, A. (ed.) 2004. Kodeks dobrej praktyki rolniczej (Code of good agricultural practice). Wyd. III, Fundacja Programow Pomocy dla Rolnictwa, Warszawa. [In Polish] 
7. Dziekanski, P. 2016. Spatial changes and assessment of the financial condition of local government units in the context of the income structure. Conference Proceedings "International Conference on Management Trends of Management in the Contemporary Society”, pp. 153-156, Mendel University in Brno.

8. Dziekanski, P. 2017. Diversification Synthetic Indicator for Evaluating the Financial Capacity of Local Government. The Case of Polish Voivodeships. Acta Universitatis Agriculturae et Silviculturae Mendelianae Brunensis, Vol. 65, Iss. 2, pp. 611-619. https://doi.org/10.11118/actaun201765020611

9. Gruszczynski, L.A. 1986. Elementy statystyki dla socjologow (Elements of statistics for sociologists). Wyd. Uniwersytetu Slaskiego, Katowice. [In Polish]

10. Kalinowski, S. 2010. Social exclusion in the rural areas - chosen indicators in the Region of Wielkopolska. Journal of Agribusiness and Rural Development, Vol. 3(17), pp. 39-46.

11. Kapitsa, U. 2012. Reducing the Impact of Agriculture and Horticulture on the Environment. In: Jakobsson, C. (ed.), Ecosystem Health \& Sustainable Agriculture. Book 1. Sustainable Agriculture, The Baltic University Programme, pp. 202-205. Uppsala.

12. Koloszko-Chomentowska, Z., Zukovskis, J., Gargasas, A. 2015. Ecological and economic sustainability of Polish and Lithuanian agricultural holdings specializing in animal production. Proceedings of the 7th International Scientific Conference "Rural Development 2015", Aleksandras Stulginskis University. https://doi.org/10.15544/RD.2015.130

13. Koreleska, E. 2016. Zachowania niemieckich konsumentow na rynku ekologicznych produktow zywnosciowych (Behaviour of German consumers in the market for organic food products). Konsumpcja i rozwoj, Vol. 3/16 (16), pp. 45-57. [In Polish]

14. Kowalska, M., Kanpik, W., Bogusz, M. 2016. Farm Education as a Component of Sustainable Development in Selected Countries of the European Union. Problems of Sustainable Development, Vol. 11, No 2, pp. 81-88.

15. Krasowicz, S. 2012. Problemy zrownowazonego rozwoju rolnictwa polskiego w swietle badan IUNG-PIB (Problems of sustainable development of Polish agriculture in the light of IUNG-PIB research). Problemy zrównoważonego gospodarowania w produkcji rolniczej, Studia i Raporty IUNG-PIB, Vol. 29(3), pp. 21-47. [In Polish]

16. Lantinga, E.A., Oomen, G.J.M., Schiere, H.B. 2000. The concept of sustainable agriculture. Pamietnik Pulawski, Vol. 120/1, pp. 263-279.

17. Marcysiak, T., Prus, P. 2009. Programy rolnosrodowiskowe jako instrument zrownowazonej modernizacji rolnictwa i obszarow wiejskich na przykladzie wybranych krajow UE (Agri-environmental schemes as instruments of sustainable modernization of agriculture and rural areas on the example of selected UE countries). Zeszyty Naukowe Szkoły Glownej Gospodarstwa Wiejskiego w Warszawie. Polityka Europejska, Finanse Publiczne, Ubezpieczenia i Marketing, Vol. 2(51), pp. 229-238. [In Polish]

18. Ogloszenie Prezesa Agencji Restrukturyzacji i Modernizacji Rolnictwa z dnia 17 wrzesnia 2014 r. w sprawie wielkosci sredniej powierzchni gruntow rolnych $\mathrm{w}$ gospodarstwie rolnym w poszczegolnych wojewodztwach oraz sredniej powierzchni gruntów rolnych w gospodarstwie rolnym w kraju w 2014 roku (Announcement of the President of the Agency for Restructuring and Modernization of Agriculture of 17 September 2014 on the size of the average area of agricultural land of a farm in individual voivodships and the average area of agricultural land of a farm in the country in 2014). Available at http://www.arimr.gov.pl/pomoc-krajowa/srednia-powierzchnia-gospodarstwa.html (Accessed on 06/11/2017) [In Polish]

19. Ogloszenie Prezesa Agencji Restrukturyzacji i Modernizacji Rolnictwa z dnia 21 wrzesnia 2015 r. w sprawie wielkosci sredniej powierzchni gruntow rolnych $w$ gospodarstwie rolnym w poszczegolnych wojewodztwach oraz sredniej powierzchni gruntów rolnych w gospodarstwie rolnym w kraju w 2015 roku (Announcement of the President of the Agency for Restructuring and Modernization of Agriculture of 21 September 2015 on the size of the average area of agricultural land of a farm in individual voivodships and the average area of agricultural land of a farm in the country in 2015). Available at http://www.arimr.gov.pl/pomoc-krajowa/srednia-powierzchnia-gospodarstwa.html (accessed on 06/11/2017) [In Polish]

20. Ogloszenie Prezesa Agencji Restrukturyzacji i Modernizacji Rolnictwa z dnia 26 wrzesnia 2016 r. w sprawie wielkosci sredniej powierzchni gruntow rolnych w gospodarstwie rolnym w poszczegolnych wojewodztwach oraz sredniej powierzchni gruntów rolnych w gospodarstwie rolnym w kraju w 2016 roku (Announcement of the President of the Agency for Restructuring and Modernization of Agriculture of 26 September 2016 on the size of the average area of agricultural land of a farm in individual voivodships and the average area of agricultural land of a farm in the country in 2016). Available at http://www.arimr.gov.pl/pomoc-krajowa/srednia-powierzchnia-gospodarstwa.html (accessed on 06/11/2017) [In Polish]

21. Ogloszenie Prezesa Agencji Restrukturyzacji i Modernizacji Rolnictwa z dnia 21 wrzesnia 2017 r. w sprawie wielkosci sredniej powierzchni gruntow rolnych $w$ gospodarstwie rolnym w poszczegolnych wojewodztwach oraz sredniej powierzchni gruntów rolnych w gospodarstwie rolnym w kraju w 2017 roku (Announcement of the President of the Agency for Restructuring and Modernization of Agriculture of 21 September 2017 on the size of the average area of agricultural land of a farm in individual voivodships and the average area of agricultural land of a farm in the country in 2017). Available at http://www.arimr.gov.pl/pomoc-krajowa/srednia-powierzchnia-gospodarstwa.html (accessed on 06/11/2017) [In Polish]

22. Paluch, L., Plonka, A. 2011. Differentiation of socio-economic and environmental development in rural municipalities in Małopolskie Province: gauging and evaluation exercise. Proceedings of the International Scientific Conference "Economic of Agriculture and Environmental Sciences in the Context of Globalization and Regional Challenges”, pp. 69-77, National University of Life and Environmental Sciences of Ukraine.

23. Paluch, L., Plonka, A. 2016. Opportunities and Threats to Sustainable Development in Environmentally Sensitive Areas in the Opinion of Local Communities. Folia Pomeranae Universitatis Technologiae Stietinensis seria Oeconomica, 85, pp. 97-106.

24. Poczta, W., Sredzinska, J., Mrowczynska-Kaminska, A. 2009. Determinanty dochodow gospodarstw rolnych Unii Europejskiej wedlug typow rolniczych (The factors determining the agricultural holdings' incomes in the European Union according to the types of farming). Zeszyty Naukowe SGGW w Warszawie-Ekonomika i Organizacja Gospodarki Zywnosciowej, 76, pp. 17-30. [In Polish]

25. Prus, P., Drzazdzynska, K. 2017. Farmers’ Assessment of Training Services and the Impact of Agricultural Advisory on Selected Developmental Factors Affecting Farming. Proceedings of the 2017 International Conference "Economic Science for Rural Development”, No 44, Jelgava, pp. 338-344, Latvia University of Agriculture. 
26. Rogers, E.M. 1995. Diffusion of innovations, 5th ed., Free Press, New York.

27. Roman, M. 2016. The Importance of a Sustainable and Smart Growth Economy in Tourism. Zeszyty Naukowe Wyzszej Szkoly Ekonomiczno-Spolecznej w Ostrolece, 2(21), pp. 168-180.

28. Rys-Jurek, R. 2008. The output of the average individual farm in Poland and in the European Union countries. An attempt of defining similarity of structures in 2005. Journal of Agribusiness and Rural Development, 2(8), pp. 119-133.

29. Rys-Jurek, R. 2009. The relations between the output, income and stock in agricultural farms. Journal of Agribusiness and Rural Development, 4(14), pp. 135-148.

30. Sigvald, S. 2012. Risk Assessments for Pests and Diseases of Field Crops, especially Forecasting and Warning Systems. In: Jakobsson, C. (ed.), Ecosystem Health \& Sustainable Agriculture. Book 1. Sustainable Agriculture, The Baltic University Programme, Uppsala, pp. 185-201.

31. Sobczyk, M. (ed.) 2004. Statystyka (Statistics), PWN, Warszawa. (In Polish)

32. Stareike, E. 2015. Organizational mechanism of rural areas development sustainability. Proceedings of the 7th International Scientific Conference "Rural Development 2015", Aleksandras Stulginskis University. https://doi.org/10.15544/RD.2015.130

33. Stefanova, M., Salek, M. 2013. Integrated farming methods and their impact on herb and bird communities of agricultural land - a $\begin{array}{lllllll}\text { review. Journal of } & \text { Central } & \text { European } & \text { Agriculture, } & 14(3), & \text { pp. } & \text { 305-317. }\end{array}$ https://doi.org/10.15544/RD.2015.116

34. Torstensson, L. 2012. Pesticides in the Environment and Risk Assessment. In: Jakobsson, C. (ed.), Ecosystem Health \& Sustainable Agriculture. Book 1. Sustainable Agriculture, The Baltic University Programme, Uppsala, p. 175-180.

35. Wojewodzic, T., Satola, L., Tabor, S. 2015. Seeking interrelations between social and economic development and indicators of farms' economic and production disagrarization. Problemy Drobnych Gospodarstw Rolnych, 4, pp. 103-119. https://doi.org/10.15576/PDGR/2015.4.103

36. Van den Ban, A.W., Hawkins, H.S. 1996. Agricultural Extension, 2nd ed., Blackwell Science.

37. Zawisza, S., Pilarska, S. 2005. Opinion leadership and information sources in agricultural innovation diffusion processes (on the basis of selected villages in the Kujawsko-Pomorskie province in Poland), EJPAU, 8(4), \#28. Available at: http://www.ejpau.media.pl/volume8/issue4/art-28.html (accessed on 06/11/2017) 